\title{
ASSOCIATIONS OF MATERNAL KNOWLEDGE AND EXCLUSIVE BREASTFEEDING WITH NUTRITION STATUS OF CHILDREN UNDER FIVE IN BANGKALAN, EAST JAVA
}

\author{
Nurun Nikmah \\ School of Health Sciences Insan Se Agung, Bangkalan
}

\begin{abstract}
Background: Nutritional status of children is one of the major predictors of child survival. Despite the various efforts, malnutrition among children remains as a major public health problem in Indonesia. Previous studies reported exclusively breastfed children were nutritionally better off and children of illiterate women were nutritionally more vulnerable than children of women who had higher education. This study aimed to determine the associations of maternal knowledge and exclusive breastfeeding (EBF) with nutrition status of children under five in Bangkalan, East Java.

Subjects and Method: This was a cross sectional study conducted at Posyandu (integrated family health post) Jagul, Bangkalan, East Java. A sample of 67 children under five years of age were selected for this study. The dependent variable was child nutrition status as measured by weight for age $\mathrm{Z}$ score. Nutritional status was classified as good if $-2 \leq \mathrm{Z}$ score $<2$, and underweight if $\mathrm{Z}$ score $<-2$. The independent variables were maternal knowledge and EBF. The data were collected by questionnaire and analyzed by a multiple logistic regression.

Results: Normal nutritional status was associated with better maternal knowledge on $\mathrm{EBF}(\mathrm{OR}=2.70 ; \mathrm{p}=0.033)$ and provision of $\mathrm{EBF}(\mathrm{OR}=2.15 ; \mathrm{p}=0.048)$.

Conclusion: Normal nutritional status of children under five is associated with better maternal knowledge on EBF and provision of EBF.
\end{abstract}

Keywords: nutritional status, maternal knowledge, exclusive breastfeeding.

\section{Correspondence:}

Nurun Nikmah. Diploma of Midwifery, School of Health Sciences Insan Se Agung, Bangkalan 69116, East Java. Email: nurunx@yahoo.co.id.

Mobile: 085755793511 